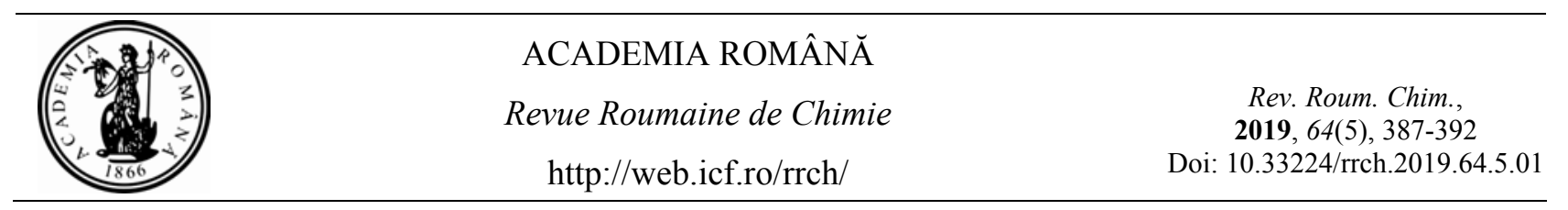

PAPERS

\title{
Pt, Pd \& Cu METAL-AMIDINE COORDINATION
}

\author{
Mohammad Bahar TAJ, ${ }^{\mathrm{a}, \mathrm{b}^{*}}$ Ahmad RAHEEL, ${ }^{\mathrm{b}}$ Syed Ahmad TIRMIZI, ${ }^{\mathrm{b} *}$ Muhammad SHARIF, \\ Roja Hammad AHMAD ${ }^{c}$ and Happipah Bint Mohd ALI ${ }^{\mathrm{d}}$ \\ ${ }^{a}$ Department of Chemistry, Islamia University, Bahawalpur, Pakistan \\ ${ }^{b}$ Department of Chemistry, Quaid-e-Azam University, Islamabad, Pakistan \\ ${ }^{c}$ Department of Nano Science and Technology, National Centre for Physics, Islamabad, Pakistan \\ ${ }^{\mathrm{d}}$ Department of Chemistry, University of Malaya, Kualalampur, Malaysia
}

Received November 28, 2016

Amidines, R'NH-C(R)=NR', as for the isoelectronic carboxylic acids, form a variety of compounds incorporating transition metals from lower to higher oxidation states. Many studies reveal that Platinum, palladium and copper metals are very active in bonding with amidine moieties. The novelty of work presented here resides in an unified approach that deals with the interpretation of various types of bonding modes shown by amidine moieties and particularly the most remarkable achievements in the design and development of platinum, palladium and copper (II) complexes of substituted amidines. Special emphasis has been focused on the identification of structural relationships for the complexes formed.

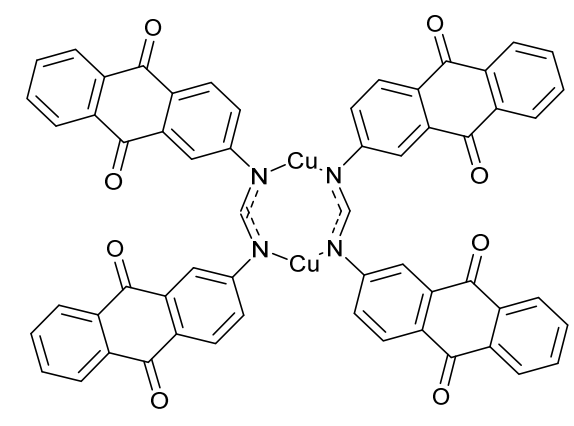

\section{INTRODUCTION}

Amidines are a very impressive class of $\mathrm{N}$-donor ligands having a central $\mathrm{sp}^{2}$-hybridized carbon, which is directly attached to an imine and amine group. ${ }^{1}$ To observe different steric and electronic properties of amidine, it can be derivatized by number of substituents at the position of nitrogen atom. ${ }^{2}$ This compatibility is a backbone to study the enormous catalytic applications of substituted amidine and valuable in probe of coordination chemistry. In addition to the resonance effect, the coordination ability of imine nitrogen to metal is greatly influenced by the presence of lone pair on formal amine nitrogen's in the " $\mathrm{CN}_{2}$ " framework. ${ }^{3}$ Neutral amidine molecules are playing active rule in coordination chemistry for almost thirty years. During current studies of their coordination chemistry, many recipes of substituted amidines have been studied, and it has been observed that the chemical properties linked with these substituted amidines can have a marked upshot on the chemistry of the resulting complexes. Amidines, being a versatile ligand, opened the door towards the discovery of the surprising coordinating mode at metals from across the periodic table. During the groundwork of this review it was grasped that maximum of the struggle has been focused to the application of amidines as a ligand, while the coordination chemistry remains comparatively immature. The purpose of this study is to focus on the binding modes of amidines particularly on the chemistry associated with coordination of platinum, palladium and copper with amidines.

\footnotetext{
* Corresponding author: drbabartaj@gmail.com (M. B. Taj) 0092300754 2669, https://orcid.org/0000-0001-5343-6893
} 
(a)<smiles>[R]N=C([R])N([R])[M]</smiles>

(e)<smiles>[R]N=C([R])N[R]</smiles>

(i)<smiles>[R]C1=NO[M]N1[R]</smiles>

(b)<smiles>[R]c1nn([R])n1[R]</smiles>

(f)<smiles></smiles>

(j)<smiles>[R][X]1=CC=C2NC([R])=N[X](C)=C2C=C1</smiles>

(c)<smiles>[R]c1nn([R])n1[R]</smiles>

(g)<smiles>[M]CN([R])C([R])N([R])[M]</smiles>

(k)<smiles></smiles>

(d)<smiles>[R]N=C1C(=[Y1])N1[R]</smiles>

(h)<smiles></smiles>

(I)<smiles></smiles>

Fig. 1 - Possible amidine bonding modes.

\section{BINDING MODE}

Fig. 1 depicted the various possible bonding modes of amidino ligand that have been confirmed by X-ray crystallography.

These bonding modes are:

(a) Monodentate. The single bonded carbon of amidine coordinated with metal atom and other doubly bonded nitrogen of amidine remained unattached. Exemplified by X-ray crystallography,

$\mathrm{PtC}_{6} \mathrm{H}_{3}\left(\mathrm{CH}_{2} \mathrm{~N}_{2}\right)_{2}\left(\mathrm{CH}_{3} \mathrm{C}_{6} \mathrm{H}_{4} \mathrm{NCHNC}_{6} \mathrm{H}_{4} \mathrm{CH}_{3}\right),{ }^{4}$ and $\mathrm{HgC}_{6} \mathrm{H}_{5}\left(\mathrm{pCH}_{3} \mathrm{C}_{6} \mathrm{H}_{4} \mathrm{NC}(\mathrm{H}) \mathrm{NC}_{6} \mathrm{H}_{4} \mathrm{CH}_{3}-\mathrm{p}\right){ }^{5}$

(b), (c), (d) Chelate complexes. This involves steric strain due to the comparatively small sized four-membered $\mathrm{M}(\mathrm{NCN})$ ring which results in distortion of the valance angles.

This class is further branched as follows:

(e) $n^{3}$-Allyl This mode is not yet recognized.

(f), (g) Bridging. This involves formation of a $\mathrm{M}_{2} \mathrm{NCN}$ ring result in metal-metal bridge.

The metal atoms may be the same as in $\mathrm{Mo}_{2}\{\mathrm{PhNC}(\mathrm{Ph}) \mathrm{NPh}\}$ or different as in $\left[2,6\left(\mathrm{CH}_{3} \& \mathrm{NCH}_{2}\right)_{2} \mathrm{C}_{6} \mathrm{H}_{3} \mathrm{Pt}[\mu-p-\right.$ $\left.\mathrm{CH}_{3} \mathrm{C}_{6} \mathrm{H}_{4} \mathrm{NC}(\mathrm{H}) \mathrm{NPr}_{i}\right] \mathrm{HgBrCl}^{6}$

(h), (i) Carbamoyl/insertion complexes. Carbamoyl complexes are formed by the insertion of the carbonyl group to metal-nitrogen bond, e.g. $\mathrm{Re}(\mathrm{CO})_{4}[\mathrm{CON}(\mathrm{Ph}) \mathrm{C}(\mathrm{Ph}) \mathrm{NPh}]^{7}$

Furthermore, in some cases is inserted a chelating amidine to form the complex $\left[\mathrm{W}_{2}(\mu \mathrm{CO})_{2}\{\mu-\right.$
$\left.\mathrm{HC}\left(\mathrm{N}-3,5-\text { xylyl }_{2}\right)_{2}\right\}\left\{\mathrm{CH}(\mathrm{N}-3,5-\mathrm{xylyl})_{2}\right\}\{(\mathrm{N}-3,5-$ xylyl $\left.\left.) \mathrm{CHN}(3,5-x y l y l) \mathrm{CH}_{2}\right\}\right]$. This is formed by the insertion of $\mathrm{CH}_{2}$ between the metal-to-nitrogen bond of bounding amidine ${ }^{8}$ and also in some other cases it has also been observed that the treatment of $\mathrm{Pt}(\mathrm{PhCN})_{2} \mathrm{Cl}_{2}$ with $\mathrm{HN}(\mathrm{Li}) \mathrm{C}\left(\mathrm{C}_{6} \mathrm{H}_{5}\right) \mathrm{NH}$ results in six-membered ring of $\mathrm{Pt}\left\{\mathrm{HNC}\left(\mathrm{C}_{6} \mathrm{H}_{5}\right) \mathrm{NC}\left(\mathrm{C}_{6} \mathrm{H}_{5}\right) \mathrm{NH}\right)_{2}$, confirmed by $\mathrm{X}$-ray crystallography. ${ }^{9}$ Possibly, this is due to the attack of nucleophile over the Nitrile group present in the reaction.

(j) Ortho-metalation. If an aryl group is substituted on the amidine nitrogen, then ortho metalation may result in the formation of stable six membered metallocycle. e.g. $\left(\pi \mathrm{C}_{5} \mathrm{H}_{5}\right) \mathrm{Pd}\left\{\mathrm{CH}_{3} \mathrm{C}_{6} \mathrm{H}_{3} \mathrm{~N}(\mathrm{H}) \mathrm{C}\left(\mathrm{CH}_{3}\right) \mathrm{N} \text {-tolyl- } p\right\}^{10}$.

This is a six membered ring, but a five-membered ring,

$\mathrm{Re}(\mathrm{CO})_{3}\left\{\mathrm{PhNC}\left(\mathrm{C}_{6} \mathrm{H}_{4}\right) \mathrm{NHPh}\right\}\{\mathrm{PhNC}(\mathrm{Ph}) \mathrm{NHPh}\}$ is established by spectroscopic methods. ${ }^{11}$

(k) Carbene. In this case amidino complex is more regarded as carbene. This simplest mode is just added for completeness, e.g. $\left[\left(\mathrm{CH}_{3} \mathrm{NC}\right)_{4} \mathrm{Ru}=\mathrm{C}\left(\mathrm{NHCH}_{3}\right)_{2}\left[\mathrm{PF}_{6}\right]{ }^{12}\right.$

(1) Metallo-amidine. Chisholm et al. recently discovered this bonding mode. The complex $\left(\mathrm{Mo}\left(\eta^{2}-\mathrm{Me}_{2} \mathrm{NCN}-2,6-\mathrm{Me}_{2} \mathrm{C}_{6} \mathrm{H}_{3}\right)_{4}\right)$ formed by the reaction of $\mathrm{Mo}\left(\mathrm{NMe}_{2}\right)_{4}$ with $2,6-\mathrm{Me}_{2} \mathrm{C}_{6} \mathrm{H}_{3} \mathrm{NC}$ is so called metallo-amidine. ${ }^{13}$ The amidine ligand can also be synthesized from simple salts, e.g. $\left[\mathrm{PhC}\left(\mathrm{NH}_{2}\right)_{2}\right]\left\{\right.$ cis- $\left.(\mathrm{OC})_{4} \mathrm{Re}\left(\mathrm{CH}_{3} \mathrm{CO}\right)_{2}\right\} .^{13}$ 


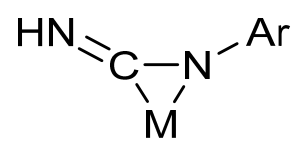<smiles>[NH2+]=C1[Y14]N1[Al]</smiles><smiles></smiles>

Fig. 2 - Bonding mode having contribution with resonance.

\section{PLATINUM AND PALLADIUM COORDINATION}

Number of workers paid keen attention to these triad of elements. To assist in the study of amidine bonding modes, Limpricht synthesized the first known amidine platinum complex by the coupling of N,N'-diphenylbenzamidine hydrochloride with platinum chloride, as $\left\{\mathrm{RNC}\left(\mathrm{R}^{\prime}\right) \mathrm{NHR} . \mathrm{HC} 1\right)_{2} \mathrm{PtCl}_{4}{ }^{14}$ After few years, in 2002 a platinum Nitrile complex has been synthesized in which two acetonitrile molecules and four ammonia molecules are bonded to central platinum metal. Many studies have been taken on six or five membered coordinating the behavior of platinum (II) synthesized a platinum Nitrile complex in which two acetonitrile molecules and four ammonia molecules are bonded to central platinum metal. Many studies have been taken on six or five membered coordinating the behavior of platinum (II). ${ }^{15}$ On different preparation routes by the use variety of substituted amidines and metals, a wide range of metal amidine complexes (R'N(X)C(R)NR') (X = H or Li) are formed. The reaction of Lithioamidines with $\mathrm{M}\left(\mathrm{C}_{6} \mathrm{H}_{5} \mathrm{CN}\right)_{2} \mathrm{Cl}_{2}$ $(\mathrm{M}=\mathrm{Pt}, \mathrm{Pd})$ results in the synthesis of $\mathrm{Pt}(\mathrm{Am})_{2}$, $\mathrm{Pd}(\mathrm{Am})_{2}$ and $\mathrm{Pd}_{2}(\mathrm{Am})_{4}$, complexes. X-ray crystallography exposed a mononuclear structure $\left(\mathrm{Pt}\left\{\mathrm{C}_{6} \mathrm{H}_{5} \mathrm{NC}\left(\mathrm{C}_{6} \mathrm{H}_{5}\right) \mathrm{NC}_{6} \mathrm{H}_{5}\right\}_{2}\right) \quad$ with symmetrical ligands of bidentate nature. ${ }^{16}$ Spectroscopic methods reveal the dimeric nature of palladium complexes in the case of formamidines $(\mathrm{R}=\mathrm{H})$ and benzamidine. Laterally the asymmetric struc- ture (Fig. 3) of one dimer ([Pd $\left.\left.\left\{\mathrm{R}^{\prime} \mathrm{NC}(\mathrm{R}) \mathrm{NR}^{\prime}\right\}_{2}\right]_{2}\right)$ has also been determined.

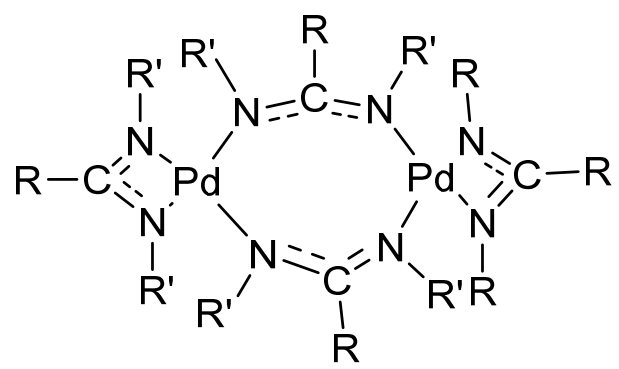

Fig. 3 - Dimeric structures for [Pd\{R'NC(R)NR' $\} 2] 2$ complexes.

The mixed ligand complexes both $\eta^{3}$-methylallyl di-p-tolylformamidino and acetamidino palladium complexes, $\left[\left(\eta^{3}-\right.\right.$ $\left.\mathrm{RC}_{3} \mathrm{H}_{4}\right) \mathrm{Pd}\left(\mathrm{R}^{\prime} \mathrm{NCHNR}\right)_{2}$ were synthesized by Al-Jibori and coworkers. ${ }^{17}$ They used the two methods, in the first one they did the reaction between two equivalents of silver amidine and $\left[\left(\eta^{3}-\mathrm{RC}_{3} \mathrm{H}_{4}\right) \mathrm{PdC} 1\right]_{2}$, whilst in method two they did the reaction between amidine and $\left[\left(\eta^{3} \mathrm{RC}_{3} \mathrm{H}_{4}\right) \mathrm{PdCl}\right]_{2}$ in the presence of $\mathrm{KOBu}_{\mathrm{t}}$. Based on spectroscopic properties, analysis of molecular weight, and closeness of crystal structures with triazine complexes are strongly confirming the way of ligand metal attraction; it was wrapped up that the bridging amidino groups are present in the dimeric nature of the complex. Toniolo et al. have ventured identical studies adopting the reaction given as follows:

$$
\begin{aligned}
& \text { (I) }\left[\mathrm{Pd}\left(\eta^{3} \text {-allyl }\right) \mathrm{C} 1\right]_{2}+2 \mathrm{Li}[\mathrm{RNC}(\mathrm{H}) \mathrm{NR}] \rightarrow\left[\mathrm{Pd}\left(\eta^{3} \text {-allyl }\right)\{\mathrm{RNC}(\mathrm{H}) \mathrm{NR}\}\right]_{2}+2 \mathrm{LiCl} \text { and } \\
& (\mathrm{II})\left[\mathrm{Pd}\left(\eta^{3} \text {-allyl }\right) \mathrm{Cl}\right]_{2}+2[\mathrm{RNHC}(\mathrm{H}) \mathrm{NR}] \rightarrow 2 \mathrm{PdCl}\{\mathrm{RNC}(\mathrm{H}) \mathrm{N}(\mathrm{H}) \mathrm{R}\}\left(\eta^{3} \text {-allyl }\right)^{18}
\end{aligned}
$$

A mixture of non-interconverting isomers (Fig. 4) were produced by the first reaction. The conformer in which allyl groups are equivalent to each other was found temperature resistant, whereas the other conformer shows an intramolecular process at 80$100^{\circ} \mathrm{C}$ resulting equivalent allyl groups. The process avoids palladium formamidino bond breaking and it is not affected by bridge splitting ligands such as N,N'-diarylformamidines or dimethyl sulphoxide. In such kind of process usually chair conformation leads to a broad inversion of the $\mathrm{C}_{2} \mathrm{~N}_{4} \mathrm{Pd}_{2}$ ring.
Temperature dependent products are obtained in second reaction. It is expected that two dynamic steps are involved in bridge splitting. In the first process (a) the breaking of bridging ligands (dissociation of the dimeric amidine complex) takes place at room temperature, and the second process (b) has low activation energy and it is concentration dependent involving chloride amidine exchange occurring via a pentacoordinated chloro bridged species. 

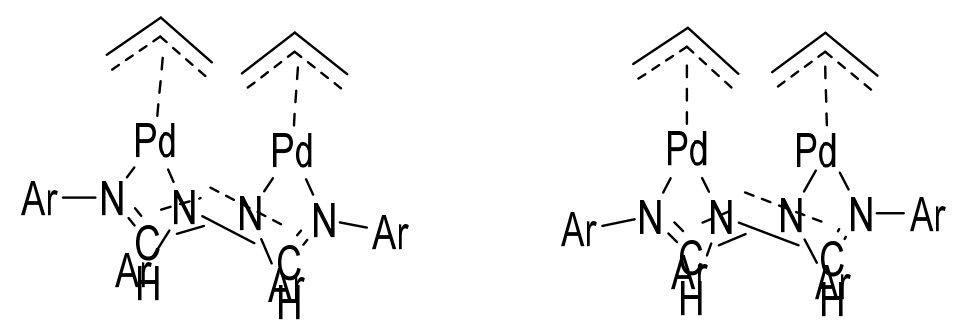

Fig. 4 - Isomeric forms of $[\operatorname{Pd}(\eta 3-a l l y l)\{R N C H N R\}] 2$.

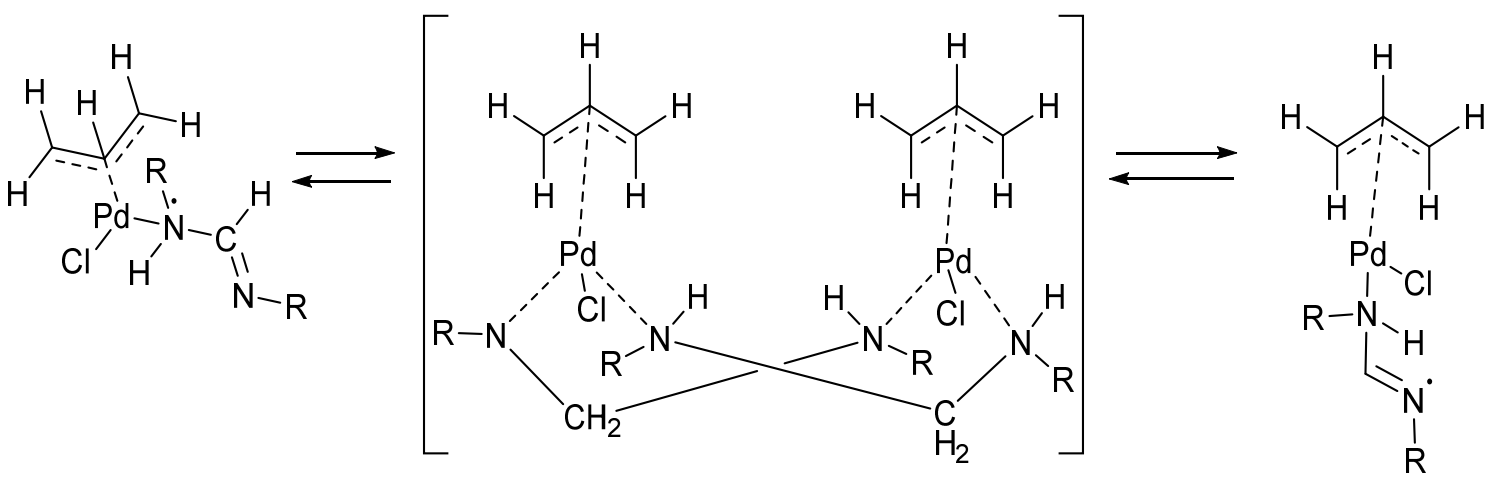<smiles>[R]N=C(CCC)[NH+]([R])[R9]([H])=CC</smiles>

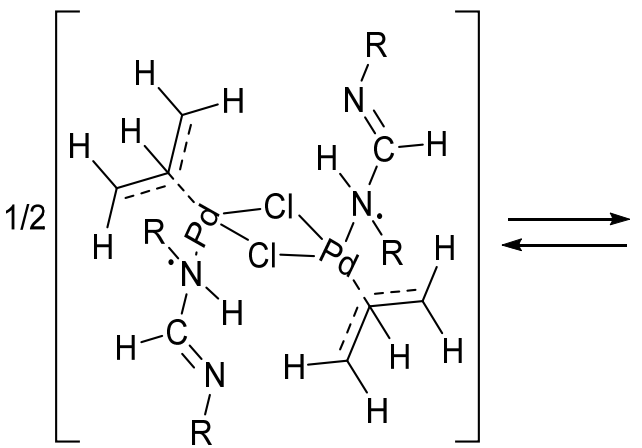<smiles></smiles>

Fig. 5 - Fluxional changes for $[\mathrm{Pd}(\eta 3$-allyl $)\{\mathrm{RNCHNHR}\} \mathrm{CI}]$.

\section{COPPER COORDINATION}

Copper (I) amidino complexes has been produced as a result of the reaction $\left[\mathrm{Pt}\left(\mathrm{CH}_{3} \mathrm{C}_{6} \mathrm{H}_{4} \mathrm{NC}(\mathrm{H}) \mathrm{NC}_{6} \mathrm{H}_{4} \mathrm{CH}_{3}\right)\left(\mathrm{C}_{6} \mathrm{H}_{3}\left\{\mathrm{CH}_{2} \mathrm{~N}\left(\mathrm{CH}_{3}\right)\right.\right.\right.$ $\left.\left.{ }_{2}\right)_{2}-2,6\right)$ and copper chloride in 1990 and the way in which amidine complexes prepared by the coupling of the dimeric o-cyanobenzyl complex with primary anilines has been examined ${ }^{19}$. The first step includes formation of a labile mononuclear amine complex due to cleavage of the Nitrile bridging group by the addition of an amine. The second, slower stage, is thought to involve the nucleophilic attack of amine nitrogen in the Nitrile carbon to produce the platinum (II) amidino species, it is the slowest step and signed as a second step (Fig. 6).<smiles>[3H][P+]([3H])(I)Cc1ccccc1C#N</smiles><smiles>C[14CH2][14CH2][14CH2][14CH2]</smiles>

$X=p-O M e: p-M e: H$ $A=$ aniline,

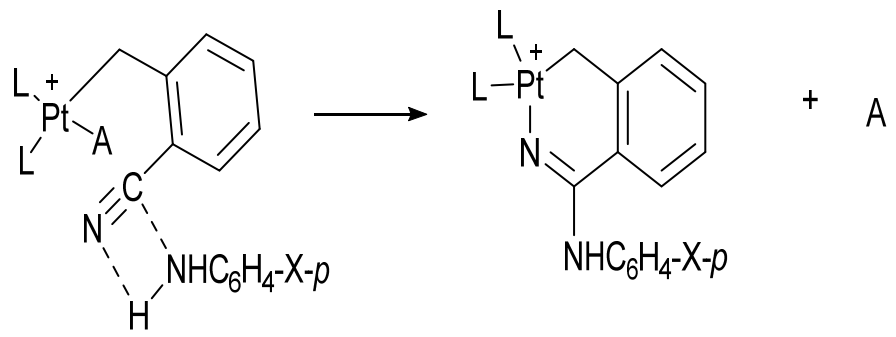

Fig. 6 - Amidine complex generated from a coordinated nitrile. 
The base of transition metal amidine chemistry is also furnished by copper coordination. Due to covalency of nitrogen and copper atoms, copperamidine complexes are mostly very fascinating, e.g. the reactions between cuprous chloride or cupric ethanoate or copper, bronze and N-1dianthraquinonylfbrmamidine gave impressive tetrameric structure (Fig. 7).

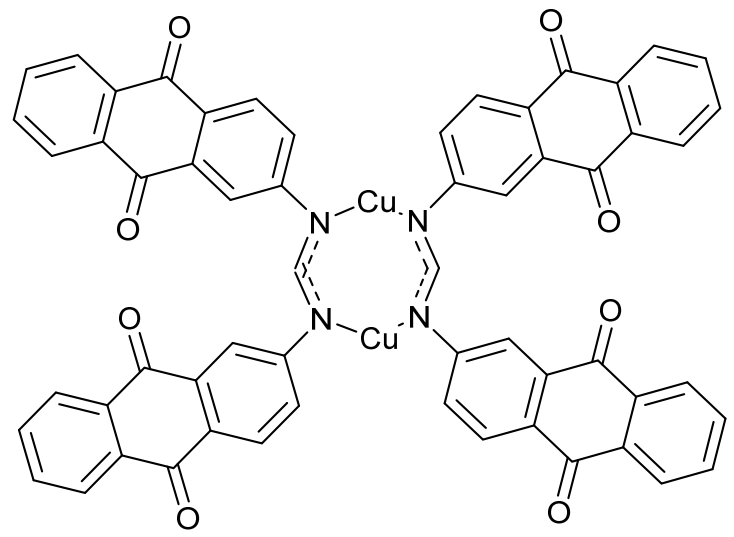

Fig. 7 - Structure originally proposed for N,N'-dianthraquinonylformamidinocopper (I).

Same structure is not produced by the reaction between copper salt and N,N'-lanthraquinonylformamidines (Fig. 8).

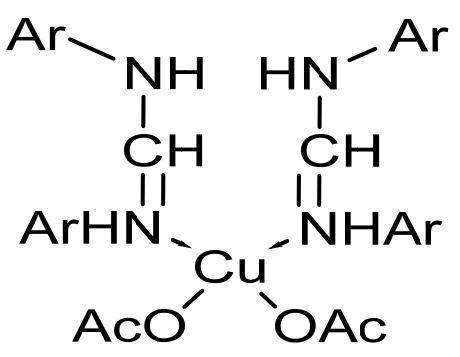

Fig. 8 - Proposed structure of [Cu(CH3COO)2(ArNHCHNAr)2].

A number of copper formamidine complexes $\left[\mathrm{M}\left\{\mathrm{RNC}(\mathrm{H}) \mathrm{NR}_{\mathrm{n}}{ }_{\mathrm{n}}\right],\left(\mathrm{R}=\mathrm{p}\right.\right.$-tolyl, $\mathrm{R}^{\prime}=\mathrm{CH}_{3}, \mathrm{C}_{2} \mathrm{H}_{4}$, $i$-propyl, t-butyl, $\left.\mathrm{C}_{6} \mathrm{H}_{11} ; \mathrm{n}=2,4\right)$ were synthesized and examined by ${ }^{1} \mathrm{H}$, and ${ }^{13} \mathrm{C} \mathrm{NMR}$, as a function of temperature, concentration, alkyl substituent and metal atom. It is concluded that they exist in the form of dimeric and tetrameric isomers (Fig. 9). For the formation of tetrameric isomers, there is needed to break one metal-nitrogen bond in each dimer and formation of two new metal-nitrogen bond. Conclusions from the study were, the bulkiness of the alkyl substituents and temperature variability is directly proportional to dimer/tetramer ratio. The reaction of copper $^{20}$ was also studied by few scientists by using trimethylsilylbenzamidinato ligands.<smiles></smiles>

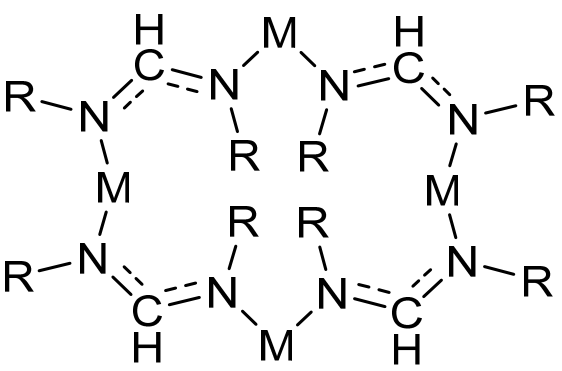

Fig. 9 - Dimeric and tetrameric forms of $[\mathrm{M}\{\mathrm{RNCHNR}\} 2] \mathrm{n}(\mathrm{M}=\mathrm{Cu} ; \mathrm{n}=2,4)$.

Infrared spectroscopy and X-ray crystallography were used for the determination of two complexes. The white dimeric crystals of copper (I) complex, $\mathrm{Cu}_{2}\left[\mathrm{C}_{6} \mathrm{H}_{5} \mathrm{C}\left\{\mathrm{NSI}\left(\mathrm{CH}_{3}\right)_{3}\right\}_{2}\right]_{2}$ was synthesized from copper chloride in refluxing acetonitrile. Amazingly the short $\mathrm{Cu}-\mathrm{Cu}$ distance of $2.42 \AA$ obtained $^{21}$ is very similar to that stated by Kilner and coworkers for the copper (II) complex, $\mathrm{Cu}_{2}\left\{\mathrm{C}_{6} \mathrm{H}_{5} \mathrm{NC}\left(\mathrm{C}_{6} \mathrm{H}_{5}\right) \mathrm{NC}_{6} \mathrm{H}_{5}\right\}$. Further, it is confirmed by $\mathrm{X}$-ray crystallography that copper (II) chloride, by the identical synthetic path, produced bidentate chelating mononuclear complex $\mathrm{C}_{6} \mathrm{H}_{5} \mathrm{C}\left(\mathrm{NSi}\left(\mathrm{CH}_{3}\right)_{3}\right)_{2} \mathrm{CuCl}\left[\mathrm{C}_{6} \mathrm{H}_{5} \mathrm{C}\left(\mathrm{NSi}\left(\mathrm{CH}_{3}\right)_{3}\right)(\mathrm{NHSi}(\right.$ $\left.\left.\left.\mathrm{CH}_{3}\right)_{3}\right)\right] \cdot{ }^{22}$

\section{CONCLUSION}

This review focuses on the most remarkable achievements in the design and development of platinum, palladium and copper (II) complexes of substituted amidines over the past few decades. The study reveals that the chemical properties of platinum amidine complexes can be modified through suitable synthetic routes. Furthermore, carefully designing of palladium complexes could be a better alternative to $\mathrm{Pt}$ (II). Based on extensive literature, researchers strongly believe that the action of copper-coordinated compounds are mainly due to the type of ligand and the donor 
atoms linked to the metal ion. This survey enlightened the fact that there are still many spaces in land of transition-metal amidine chemistry which is needing to be explored and exploited. The structural aspects, variety of bonding modes exhibited by amidine, enforce the mind to operate in this area.

Acknowledgements. This work was supported by IRSIP under Higher Education Commission of Pakistan (HEC), Quaid-e-Azam University, Islamabad (QAU), Pakistan and University of Malaya (UM), Kualalampur, Malaysia.

\section{REFERENCES}

1. C. M. Kelly, 2017.

2. A. G. Tskhovrebov, K. V. Luzyanin, M. L. Kuznetsov, V. N. Sorokoumov, I. A. Balova, M. Haukka and V. Y. Kukushkin, Organometallics, 2011, 30, 863-874.

3. Q. Shi, Phd thesis, University of York, 2010.

4. J. Barker and M. Kilner, Coord. Chem. Reviews, 1994, 133, 219-300.

5. J. Wu, X. Pan, L. Yao, L. Wang and N. Tang, Supramolec. Chem., 2009, 21, 707-716.

6. D. Yüksel, 2013.

7. Z. D. Brown, P. Vasko, J. D. Erickson, J. C. Fettinger, H. M. Tuononen and P. P. Power, J. Am. Chem. Soc., 2013, 135, 6257-6261.

8. F.-H. Wang, Y.-X. Ji and J.-J. Wang, J.Hazardous Mater, 2012, 241, 427-432.
9. P. V. Gushchin, M. R. Tyan, N. A. Bokach, M. D. Revenco, M. Haukka, M.-J. Wang, C.-H. Lai, P.-T. Chou, and V. Y. Kukushkin, Inorg. Chem., 2008, 47, 11487-11500.

10. M. J. Miah, M. P. Sibi, S. Chattopadhyay, O. B. Familoni and V. Snieckus, Euro. J. Org. Chem., 2018, 2018, 440446.

11. S. Miguel-Fernández, S. Martinez de Salinas, J. Diez, M.Gamasa and E. Lastra, Inorg. Chem., 2013, 52, 42934302.

12. S. Chuprakov, B. T. Worrell, N. Selander, R. K. Sit and V. V. Fokin, J. Am. Chem. Soc., 2013, 136, 195-202.

13. M. H. Chisholm, C. E. Hammond, D. Ho and J. C. Huffman, J. Am. Chem. Soc., 1986, 108, 7860-7861.

14. H. E. Armstrong, "A History of Chemistry", Springer, 1964, p. 801-872.

15. V. Y. Kukushkin and A. J. Pombeiro, Chem. Reviews, 2002, 102, 1771-1802.

16. J. Barker, Phd thesis, Durham University, 1985.

17. S. A. Al-Jibori, A. S. Al-Zaubai, M. Y. Mohammed and T. A. Al-Allaf, Trans. Metal Chem., 2007, 32, 281-286.

18. L. Toniolo, T. Boschi and G. Deganello, J. Organometallic Chem., 1975, 93, 405-414.

19. G. Van Koten, J. A. Van Beek, I. C. Wehman-Ooyevaar, F. Muller, C. H. Stam and J. Terheijden, Organometallics, 1990, 9, 903-912.

20. E. Ruiz, J. Cano, S. Alvarez and P. Alemany, J. Am. Chem. Soc., 1998, 120, 11122-11129.

21. A. Márquez, E. Ávila, C. Urbaneja, E. Álvarez, P. Palma and J. Cámpora, Inorg. Chem., 2015, 54, 11007-11017.

22. H. E. Abdou, A. A. Mohamed and J. P. Fackler Jr, "Gold (I) nitrogen chemistry", WILEY-VCH Verlag Gmbh \& Co. KGaA: Weinheim, 2009. 